\title{
Life Space Assessment in Stroke Patients
}

\author{
You-Na Yang, $\mathrm{MD}^{1}$, Bo-Ram Kim, MD, PhD ${ }^{1}$, Kyeong Eun Uhm, $\mathrm{MD}^{1}$, Soo Jin Kim, $\mathrm{MD}^{1}$, \\ Seunghwan Lee, $\mathrm{MD}^{1}$, Mooyeon Oh-Park, $\mathrm{MD}^{2}$, Jongmin Lee, $\mathrm{MD}$, $\mathrm{PhD}^{1,3}$
}

\begin{abstract}
${ }^{1}$ Department of Rehabilitation Medicine, Konkuk University School of Medicine and Konkuk University Medical Center, Seoul, Korea; ${ }^{2}$ Department of Physical Medicine and Rehabilitation, Rutgers New Jersey Medical School, Newark, NJ, USA; Kessler Institute for Rehabilitation, West Orange, NJ; Kessler Foundation, West Orange NJ, USA; ${ }^{3}$ International Healthcare Research Institute, Konkuk University, Seoul, Korea
\end{abstract}

\begin{abstract}
Objective To evaluate the reliability of the practical life space in post-stroke patients using the Korean version of the Life-Space Assessment (K-LSA) questionnaire and to assess the relationships between the K-LSA and physical function, daily activity, quality of life, and post-stroke depression.

Methods The LSA questionnaire was translated into Korean, and the translated version was authorized by the author of the LSA questionnaire. In a cross-sectional study, the performance of the K-LSA was evaluated in 34 stroke patients (20 males and 14 females; mean age $65.11 \pm 2.39$ years) who were receiving physical and occupational therapy at the outpatient clinic in the rehabilitation medicine department of a university medical center at the time of evaluation. Performances were assessed twice by one examiner at a 2-week interval to test the reliability. The patients were evaluated using the Functional Ambulation Category (FAC) scale, Functional Independence Measure (FIM) scale, and mobility subscale of the FIM to assess their relationships with the K-LSA. They were also evaluated using the EuroQol 5 Dimensions questionnaire (EQ-5D) and Geriatric Depression Scale (GDS) to determine the relationship with quality of life and post-stroke depression.

Results Test-retest reliability at the first $(62.20 \pm 32.14)$ and second $(63.15 \pm 32.22)$ assessment was $0.993(\mathrm{p}<0.01)$. The K-LSA showed significant correlations with the FAC ( $r=0.848, \mathrm{p}<0.01)$, FIM $(\mathrm{r}=0.765, \mathrm{p}<0.01)$, mobility category of the FIM ( $r=0.764, \mathrm{p}<0.01)$, GDS ( $\mathrm{r}=-0.657, \mathrm{p}<0.01)$, and EQ-5D ( $\mathrm{r}=0.506, \mathrm{p}<0.01)$.

Conclusion This study suggests that the practical life space of post-stroke patients, assessed by the K-LSA, has a significant correlation with patients' functional mobility, independence in daily activity, quality of life, and depression.
\end{abstract}

Keywords Life space, Stroke, Mobility, Quality of life, Depression

Received February 3, 2017; Accepted March 31, 2017

Corresponding author: Jongmin Lee

Department of Rehabilitation Medicine, Konkuk University Medical Center, 120-1 Neungdong-ro, Hwayang-dong, Gwangjin-gu, Seoul 05030, Korea. Tel: +82-2-2030-5345, Fax: +82-2-2030-5379, E-mail: leej@kuh.ac.kr

ORCID: You-Na Yang (http://orcid.org/0000-0001-8149-9920); Bo-Ram Kim (http://orcid.org/0000-0002-5463-1268); Kyeong Eun Uhm (http://orcid. org/0000-0003-2714-1092); Soo Jin Kim (http://orcid.org/0000-0001-6539-6497); Seunghwan Lee (http://orcid.org/0000-0002-7037-3254); Mooyeon Oh-Park (http://orcid.org/0000-0003-0115-0804); Jongmin Lee (http://orcid.org/0000-0001-8718-0099).

(c) This is an open-access article distributed under the terms of the Creative Commons Attribution Non-Commercial License (http://creativecommons.org/ licenses/by-nc/4.0) which permits unrestricted noncommercial use, distribution, and reproduction in any medium, provided the original work is properly cited. Copyright $\odot 2017$ by Korean Academy of Rehabilitation Medicine 


\section{INTRODUCTION}

The concept of life space, defined as an area in which people move in daily life, has been developed to estimate the movement of individual patients from home to beyond town or region [1-3]. Among various instruments, the Life-Space Assessment (LSA) questionnaire of the Alabama and Birmingham Study of Aging assesses the usual pattern of individual mobility during the month preceding the time of evaluation, and it examines mobility based on how far one moves across 5 levels (from home to out-of-town) [2]. The resulting overall LSA score documents mobility not only for the distance and frequency of movement, but also for any assistance needed by a person who moves to each of the defined levels.

Baker et al. [2] evaluated the validity and reliability of a standardized approach for assessing life-space mobility in community-dwelling older adults. Peel et al. [3] described statistically significant relationships between LSA and traditional measures of physical function, sociodemographic characteristics, depression, and cognitive status in older adults, and Polku et al. [4] reported significant associations between life space and depressive symptoms among older community-dwelling people. A study in Brazil examined post-stroke patients in their life spaces [5], but there is little research on life space assessment in stroke patients. The relationships between LSA scores in stroke patients and their quality of life (QOL) and post-stroke depression have not been evaluated, although these psychologic and sociodemographic characteristics substantially affect the life space of communitydwelling adults [3].

The LSA questionnaire has been translated into multiple languages including Spanish [1], Japanese [6], French-Canadian [7], Finnish [8], Chinese [9], and Swedish [10]. Translation of a new instrument into the native language and cross-cultural modifications are essential for its use in another country that speaks a different language [11]. However, the concept of life space and the LSA have never been introduced in Korea.

The purpose of the study was to evaluate the post-stroke patients' practical life space using the LSA, which is the most representative questionnaire for life space evaluation, by translating it into Korean, and to describe the relationships between the K-LSA and physical and daily function, quality of life, and post-stroke depression.

\section{MATERIALS AND METHODS}

\section{Translation of the LSA into Korean}

The LSA was translated into Korean (Version 1) by two physiatrists fluent in English. Another physiatrist reviewed the first version of the translation, and then, these three physiatrists discussed Version 1. A reconciled version (Version 2) was achieved by consensus and it was back-translated into English by two other translators who majored in English literature (Version 3). Version 3 was reviewed and compared to the original version by two physiatrists.

To test the applicability of the instrument in stroke patients in Korea, we conducted a cross-sectional study using the Korean version of the Life-Space Assessment (KLSA) among community-dwelling stroke patients.

The Korean version generally preserves the meaning of the original version. To convey the meaning of "neighborhood" or "town" clearly, "town" can be translated as "Eub, Myun, or Gu" in Korean. However, the level does not have to follow definite administrative units, because the original University of Alabama at Birmingham (UAB)LSA conceptual model shows life-space levels as a series of concentric areas radiating from the room where a person sleeps. In our study, each level was divided by the radius in ' $k m$ '; for example, level 3 indicates a place within $1 \mathrm{~km}$, where subjects can go on foot; level 4 indicates a place within $10 \mathrm{~km}$, and level 5 indicates a place at more than $10-\mathrm{km}$ radius (Appendix 1).

\section{Study population}

The subjects were 34 stroke patients receiving outpatient rehabilitation treatment at a university medical center in August 2016. Inclusion criteria were diagnosis of ischemic or hemorrhagic stroke, and patients' ability to provide information about their mobility or daily functional status by themselves or through a caregiver. Every patient receiving outpatient rehabilitation was assessed, regardless of the lesion and duration of stroke. Exclusion criteria were quadriplegia, inability to move either side of the body, and recent severe pain or medical condition that could affect mobility.

\section{Assessment using the K-LSA}

The K-LSA was administered through a face-to-face assessment by an occupational therapist at baseline, and 
test-retest reliability of the instrument was estimated by reassessing these 34 stroke patients 2 weeks later. Reassessments were carried out by the same examiner. The KLSA used the same scoring system as in the UAB Study of Aging Life-Space Assessment which was used to identify the distance through which a person reported moving during the 4 weeks prior to assessment [3].

The life-space zones are determined by distances moved in daily movement patterns, ranging from a person's bedroom (level 1) to beyond the person's town (level 5 ). The five levels were selected by asking the following questions: (1) "During the past 4 weeks, have you been to other rooms of your home besides the room where you sleep (level 1)?"; (2) "During the past 4 weeks, have you been to an area immediately outside your home such as your porch, deck, patio, hallway of an apartment building, or garage (level 2)?"; (3) "During the past 4 weeks, have you been to places in your immediate neighborhood, but beyond your own property or apartment building (level 3)?"; (4) "During the past 4 weeks, have you been to places outside your immediate neighborhood but within your town (level 4)?"; and (5) "During the past 4 weeks, have you been to places outside your immediate town (level 5)?" For each life-space level, subjects were asked how often they moved to that area (less than once a week, 1-3 times each week, 4-6 times each week, or daily) and whether they needed assistance from another person or from an assistive device ('yes' versus 'no'). The K-LSA was scored by assigning a value to each of the 5 levels and then summing the 5 scores. Level scores were obtained by multiplying the life-space level (1-5), the degree of independence ( $2=$ no assistance, $1.5=$ equipment only, $1=$ personal assistance), and the frequency of movement ( $1=$ less than once a week, $2=1-3$ times each week, $3=4-6$ times each week, and $4=$ daily). The total K-LSA scores ranged from 0 (totally bed-bound) to 120 (moved out of town every day without assistance) [3].

\section{Clinical assessments}

Patients were also evaluated using the Functional Ambulation Category (FAC) scale, Functional Independence Measure (FIM) scale, and mobility subscale of the FIM to assess the validity of the K-LSA. The FAC categorizes patients using 6 scales according to basic motor skills necessary for functional ambulation [12]. The FIM assesses basic activities of daily living using 18 subscales, and the subscales are divided into motor FIM for physical functioning and cognitive FIM for cognitive, behavioral, and communicative functioning. Motor FIM consists of self-care (eating, grooming, bathing, dressing, toileting), sphincter control (bladder management, bowel management), transfers (bed/chair/wheelchair, toilet, tub/shower), and locomotion (walk/wheelchair, stairs). Cognitive FIM consists of communication (comprehension, expression) and social cognition (social interaction, problem solving and memory) [13].

The EuroQol 5 Dimensions questionnaire (EQ-5D) and Geriatric Depression Scale (GDS) were also used to identify the relationships between life space, quality of life, and post-stroke depression. EQ-5D was developed in Europe and it evaluates the generic quality of life [14]; health status is measured in terms of 5 dimensions (5D): mobility, self-care, usual activities, pain/discomfort, and anxiety/depression. The mobility dimension asks about the person's walking ability. The self-care dimension asks about the ability to wash or dress by oneself, and the usual activities dimension measures performance in "work, study, housework, family or leisure activities." In the pain/discomfort dimension, it asks how much pain or discomfort they have, and in the anxiety/depression dimension, it asks how much anxious or depressed they feel. GDS is a self-reporting instrument designed to screen for clinical depression in the elderly; the scale consists of 30 yes or no questions. One point is assigned to each answer, and the cumulative score is rated on a grid. The grid sets a range of $0-9$ as normal, 10-19 as mildly depressed, and 20-30 as severely depressed; a higher score indicates a higher probability of depression [15].

These clinical assessments were made by an occupational therapist experienced in scoring of the K-LSA to assess the validity and to assess its relationship with quality of life and post-stroke depression.

\section{Statistical analyses}

Statistical analyses were conducted using SPSS ver. 17.0 for Windows (SPSS Inc., Chicago, IL, USA). Pearson correlation coefficient analysis was used to assess test-retest reliability, and Spearman correlation was used to evaluate the correlation between the K-LSA and other functional measures. 


\section{RESULTS}

\section{Demographic characteristics}

Thirty-four subjects (20 males and 14 females; mean age $65.11 \pm 2.39$ years) with stroke were evaluated. Twenty-two participants had ischemic stroke, and 12 participants had hemorrhagic stroke. Table 1 summarizes the demographics and clinical characteristics of patients with mean values for the FAC, FIM, and mobility subscale of the FIM.

\section{Test-retest reliability of the K-LSA}

The test-retest reliability of the K-LSA was analyzed using Pearson correlation coefficient. The kappa value of the test was $0.993(\mathrm{p}<0.01)$, and the mean K-LSA scores were $62.20 \pm 32.14$ at the first assessment and $63.15 \pm 32.22$ at the second assessment (Table 2).

\section{Relationships between the K-LSA and other functional measures}

With Spearman analysis, the K-LSA showed significant positive correlations with the FAC $(r=0.848, p<0.01)$, FIM $(\mathrm{r}=0.765, \mathrm{p}<0.01)$, and the mobility subscale of the FIM $(\mathrm{r}=0.764, \mathrm{p}<0.01)$. The K-LSA also showed a positive correlation with EQ-5D $(r=0.506, p<0.01)$, and a negative

Table 1. Characteristics of 34 stroke patients

\begin{tabular}{|lc|}
\hline \multicolumn{1}{|c}{ Variable } & Value \\
\hline Age $(\mathrm{yr})$ & $65.11 \pm 2.39$ \\
\hline Sex & \\
\hline Male & 20 \\
\hline Female & 14 \\
\hline Type of stroke & \\
\hline Ischemic & 22 \\
\hline Hemorrhagic & 12 \\
\hline FIM & $109.32 \pm 3.51$ \\
\hline FIM-mobility subscale & $30.21 \pm 1.37$ \\
\hline FAC & $4.00 \pm 0.25$ \\
\hline EQ-5D & $0.66 \pm 0.04$ \\
\hline GDS & $8.09 \pm 0.72$ \\
\hline K-LSA total score $(0-120)$ & $42.29 \pm 3.68$ \\
\hline
\end{tabular}

Values are presented as mean \pm standard deviation. FIM, Functional Independence Measure; FAC, Functional Ambulation Category; GDS, Geriatric Depression Scale; EQ-5D, EuroQol 5 Dimensions questionnaire; LSA, Life Space Assessment. correlation with GDS $(\mathrm{r}=-0.657, \mathrm{p}<0.01)($ Table 3$)$.

\section{DISCUSSION}

The results of this study showed that the K-LSA is a reliable tool for assessing the mobility and it is highly correlated with physical function, quality of life, and psychological status of stroke patients. To the best of our knowledge, this is the first study to assess the relationship between the expanded domain of mobility and the FAC and FIM among stroke patients.

Mobility, ability to move around, is one the main goals for management of stroke patients. Clinicians usually use the traditional assessment tools, interview-based measures (e.g., the Modified Barthel Index) and performance-based measures including the FIM, Berg Balance Scale, or Timed Up and Go Test, etc. These scales provide valuable information about stroke patients' mobility in a specific setting; however, they may not adequately capture the full extent of mobility of patients living in the community. In addition, traditional mobility scales often assess patients' inability to move rather than how much they can actually move around. Therefore, the LSA can serve as a complementary tool to the traditional mobility measures for providing information about community mobility among stroke patients. The concept of life-space was initially described in the geriatrics and gerontology literature. Several life-space measures are available for

Table 2. Test-retest reliabilities

\begin{tabular}{ccc}
\hline Assessment & Mean \pm SD & p-value \\
\hline 1st assessment & $62.20 \pm 32.14$ & $\mathrm{p}<0.01$ \\
2nd assessment & $63.15 \pm 32.22$ & $\mathrm{p}<0.01$ \\
\hline
\end{tabular}

Table 3. Correlation of the K-LSA with the FAC, FIM, mobility subscale of the FIM, EQ-5D, and GDS

\begin{tabular}{lrcc}
\hline & Mean \pm SD & rho & p-value \\
\hline FAC & $4.00 \pm 0.25$ & 0.848 & 0.01 \\
FIM & $109.32 \pm 3.51$ & 0.765 & 0.01 \\
FIM mobility subscale & $30.21 \pm 1.37$ & 0.764 & 0.01 \\
EQ-5D & $0.66 \pm 0.04$ & 0.506 & 0.01 \\
GDS & $8.09 \pm 0.72$ & -0.657 & 0.01 \\
\hline
\end{tabular}

FAC, Functional Ambulation Category; FIM, Functional Independence Measure; GDS, Geriatric Depression Scale; EQ-5D, EuroQol 5 Dimensions questionnaire; LSA, Life-Space Assessment. 
various populations.

May et al. [16] introduced the first measure of lifespace, the Life-Space Diary, in 1985 for older adults living in the community. For the Life-Space Diary, life-space was divided into 5 concentric zones: the bedroom; the rest of the dwelling; the garden, courtyard, or grounds surrounding the dwelling; the 'block' in which the dwelling is located; and the area across a traffic-bearing street. Participants were instructed to record the zones in which they moved daily for one month. One important feature of the diary was that it presented what the subjects actually did rather than what they were capable of doing. In 1990, Tinetti and Ginter [17] introduced the Nursing Home Life-Space Diameter (NHLSD), an adaptation of the Life-Space Diary to the nursing home setting. Lifespace in the nursing home was divided into the following zones: the resident's room, outside the room but within the unit, outside the unit but within the facility, and outside the facility. Staff members rated residents based on how often they moved within each of the zones over a 2-week period. Stalvey et al. [18] introduced the LifeSpace Questionnaire (LSQ) in 1999. This questionnaire was designed to capture a broader range of environmental regions characteristic of community-dwelling older adults. The LSQ consists of 9 questions that ask whether respondents have been to certain regions within their environment within the past 3 days. The regions range from the rooms within their home to move out of the region of the United States in which they reside. However, the currently used assessments inadequately describe the full continuum of mobility observed in community-dwelling older adults, and they often measure the result of mobility loss rather than mobility itself [2]. Among the lifespace instruments, the LSA questionnaire of the Alabama and Birmingham Study assesses the usual pattern of individual mobility during the month preceding the time of evaluation, and it examines mobility based on how far one moves across the five levels, as mentioned above [2]. Then, the resulting overall LSA score documents the practical mobility based on not only how far but also how often a person moves to each of the defined levels and whether any assistance is needed to get to each level.

There have been a few studies assessing the life-space in stroke patients. Estima et al. [5] examined the validity of life-space assessment in Brazilian stroke patients and the interaction between their functional ability and external factors. Unlike our study, the inclusion criterion was having been diagnosed with only hemiplegia caused by stroke and the exclusion criterion was having been diagnosed with dementia. In the study, the LSA was valid in a population of chronic stroke survivors, with excellent reliability, and it correlated significantly with measurements of body structure, function, and motor activities. Clearly, this scale is likely to be a more useful measure for ambulatory patients or in conditions where they can move even if they are accompanied by a caregiver with the assistive aids. Moving outside the residence reflects motivation, social interaction and network, and engagement in pleasurable activities by an individual beyond the physical distance of movement. In particular, the use of the following scales in ambulatory stroke patients is likely to be a meaningful stroke measure to observe how well they actually adapt to their lives after discharge from a hospital. In the same vein, our results support the hypothesis that the extent of how far and how often a person can move would positively correlate with the quality of life. These findings are consistent with a previous study which showed a correlation between the traditional mobility measure (FIM) and EQ-5D in stroke patients [14]. In our study, life-space of a person was negatively correlated with depression scores.

Life-space was also used as an outcome measure for stroke patients with specific impairment. In this study, the severity of neglect predicted community mobility measured by the LSA in stroke patients 6 months post discharge [19]. We expect that the life-space assessment will be utilized more in the future for clinical and research purposes, and community mobility is recognized as a functional goal for management of stroke patients. In future studies, other than the relationship between the KLSA and traditional physical and functional assessment tools, the relationships with other life space assessment tools should be assessed for further evaluation of the KLSA. Moreover, as other studies have revealed that the lack of social and material resources restricts patients' actual life space independently of physical performance and mobility [1], various socio-demographic factors such as familial support, financial status, and location of residency should be considered to evaluate the factors related to the patients' dwelling life space level.

As expected, life space was strongly associated with quality of life and depressed mood. Therefore, by identi- 
fying the factors that contribute to K-LSA scores, physicians and physical therapists can develop clinical hypothesis to explain mobility deficits, and can design care plans to address the contributing factors.

There are several limitations in this study. First, this study was conducted with relatively small number of stroke patients in the chronic stage. Therefore, the results may not be applicable to stroke patients in a relatively early stage of rehabilitation. Second, all patients who could not follow the instructions were excluded, and although the participants answered the questions consistently, a formal cognitive test may be used in future studies. Third, although the cross-sectional design of this study limits examination of any causal relationship between depression and the life-space, it is plausible to hypothesize that depression may affect mobility and vice versa. We plan to investigate this hypothesis in future studies to design care plans to address depression and community mobility in stroke patients.

In conclusion, the Korean version of the LSA displayed significant test-retest reliability, and it was correlated with traditional physical and functional assessment tools such as the FAC, FIM, and the mobility subscale of the FIM. Moreover, the K-LSA also showed a significant correlation with the quality of life and post-stroke depression. Therefore, the K-LSA can be useful for functional assessment of the range of life space in Korean community-dwelling stroke patients.

\section{CONFLICT OF INTEREST}

No potential conflict of interest relevant to this article was reported.

\section{ACKNOWLEDGMENTS}

This paper was supported by Konkuk University in 2016.

\section{REFERENCES}

1. Curcio CL, Alvarado BE, Gomez F, Guerra R, Guralnik J, Zunzunegui MV. Life-Space Assessment scale to assess mobility: validation in Latin American older women and men. Aging Clin Exp Res 2013;25:553-60.

2. Baker PS, Bodner EV, Allman RM. Measuring life- space mobility in community-dwelling older adults. J Am Geriatr Soc 2003;51:1610-4.

3. Peel C, Sawyer Baker P, Roth DL, Brown CJ, Brodner $\mathrm{EV}$, et al. Assessing mobility in older adults: the UAB Study of Aging Life-Space Assessment. Phys Ther 2005;85:1008-119.

4. Polku H, Mikkola TM, Portegijs E, Rantakokko M, Kokko K, Kauppinen M, et al. Life-space mobility and dimensions of depressive symptoms among community-dwelling older adults. Aging Ment Health 2015; 19:781-9.

5. Estima AE, Dutra BM, Martins JV, Franzoi AC. Validation of the "Life Space Assessment - LSA" Questionnaire in a group of hemiplegic patients. Acta Fisiatr 2015;22:1-4.

6. Shimada H, Sawyer P, Harada K, Kaneya S, Nihei K, Asakawa $Y$, et al. Predictive validity of the classification schema for functional mobility tests in instrumental activities of daily living decline among older adults. Arch Phys Med Rehabil 2010;91:241-6.

7. Auger C, Demers L, Gelinas I, Routhier F, Jutai J, Guerette C, et al. Development of a French-Canadian version of the Life-Space Assessment (LSA-F): content validity, reliability and applicability for power mobility device users. Disabil Rehabil Assist Technol 2009; 4:31-41.

8. Rantanen T, Portegijs E, Viljanen A, Eronen J, Saajanaho M, Tsai LT, et al. Individual and environmental factors underlying life space of older people - study protocol and design of a cohort study on life-space mobility in old age (LISPE). BMC Public Health 2012; 12:1018.

9. Ji M, Zhou Y, Liao J, Feng F. Pilot study on the Chinese version of the Life Space Assessment among community-dwelling elderly. Arch Gerontol Geriatr 2015;61: 301-6.

10. Kammerlind AS, Fristedt S, Ernsth Bravell M, Fransson EI. Test-retest reliability of the Swedish version of the Life-Space Assessment Questionnaire among community-dwelling older adults. Clin Rehabil 2014; 28:817-23.

11. Beaton DE, Bombardier C, Guillemin F, Ferraz MB. Guidelines for the process of cross-cultural adaptation of self-report measures. Spine (Phila Pa 1976) 2000;25: 3186-91.

12. Holden MK, Gill KM, Magliozzi MR, Nathan J, Piehl- 
Baker L. Clinical gait assessment in the neurologically impaired. Reliability and meaningfulness. Phys Ther 1984;64:35-40.

13. Hamilton BB, Laughlin JA, Fiedler RC, Granger CV. Interrater reliability of the 7-level functional independence measure (FIM). Scand J Rehabil Med 1994;26: 115-9.

14. Schrag A, Selai C, Jahanshahi M, Quinn NP. The EQ5D: a generic quality of life measure-is a useful instrument to measure quality of life in patients with Parkinson's disease. J Neurol Neurosurg Psychiatry 2000;69:67-73.

15. Goyal A, Kajal KS. Prevalence of depression in elderly population in the southern part of punjab. J Family Med Prim Care 2014;3:359-61.
16. May D, Nayak US, Isaacs B. The life-space diary: a measure of mobility in old people at home. Int Rehabil Med 1985;7:182-6.

17. Tinetti ME, Ginter SF. The nursing home life-space diameter. A measure of extent and frequency of mobility among nursing home residents. J Am Geriatr Soc 1990;38:1311-5.

18. Stalvey BT, Owsley C, Sloane ME, Ball K. The lifespace questionnaire: a measure of the extent of mobility of older adults. J Appl Gerontol 1999;18:460-78.

19. Oh-Park M, Hung C, Chen P, Barrett AM. Severity of spatial neglect during acute inpatient rehabilitation predicts community mobility after stroke. PM R 2014; 6:716-22. 
Appendix 1. Korean version of the Life-Space Assessment (LSA)

\begin{tabular}{|c|c|c|c|c|c|c|c|c|}
\hline \multicolumn{6}{|l|}{ 이름: } & \multicolumn{3}{|c|}{ 날짜: } \\
\hline \multicolumn{9}{|c|}{ 다음 질문들은 지난 한 달 간의 일상생활 활동 범위를 묻는 것입니다. } \\
\hline \multicolumn{3}{|c|}{ 생활공간범위 } & \multicolumn{4}{|c|}{ 빈도 } & 독립성 & 점수 \\
\hline \multicolumn{3}{|c|}{$\begin{array}{l}\text { 지난 4주간 다음 장소에 간 적이 } \\
\text { 있나요? }\end{array}$} & \multicolumn{4}{|c|}{ 얼마나 자주 갔나요? } & $\begin{array}{l}\text { 보조도구나 장비를 } \\
\text { 사용했나요? 타인의 } \\
\text { 도움이 필요했나요? }\end{array}$ & $\begin{array}{l}\text { 범위× } \\
\text { 빈도x } \\
\text { 독립성 }\end{array}$ \\
\hline \multirow{2}{*}{$\begin{array}{r}\text { 생활공간범위 } 1 \ldots \\
\text { 침실 이외의 다른 방 } \\
\text { 점수 } \\
\end{array}$} & 예 & 아니오 & $\begin{array}{c}\begin{array}{c}1 \text { 번 미만 } \\
/ 1 \text { 주 } \\
1\end{array} \\
\end{array}$ & $\begin{array}{c}\text { 1-3번 } \\
/ 1 \text { 주 } \\
2\end{array}$ & $\begin{array}{c}\text { 4-6번 } \\
\text { /1주 } \\
3\end{array}$ & $\begin{array}{c}\text { 매일 } \\
4\end{array}$ & $\begin{array}{l}1=\text { 타인의 도움 } \\
1.5=\text { 보조도구만 사용 } \\
2=\text { 둘 다 필요 없음 }\end{array}$ & \multirow{3}{*}{ 범위 1 점수 } \\
\hline & \multicolumn{5}{|c|}{$X$} & \multicolumn{2}{|c|}{$x$} & \\
\hline $\begin{array}{l}\text { 생활공간범위 } 2 \ldots \\
\text { 베란다, 아파트복도, } \\
\text { 건물 출입구, 주차장, } \\
\text { 마당 등 집 근처 실외 } \\
\text { 공간 }\end{array}$ & 예 & 아니오 & $\begin{array}{l}\text { 1번 미만 } \\
\text { /1주 }\end{array}$ & $\begin{array}{l}\text { 1-3번 } \\
/ 1 \text { 주 }\end{array}$ & $\begin{array}{l}\text { 4-6번 } \\
\text { /1주 }\end{array}$ & 매일 & \multirow{2}{*}{$\begin{array}{l}1=\text { 타인의 도움 } \\
1.5=\text { 보조도구만 사용 } \\
2=\text { 둘 다 필요 없음 } \\
x=\end{array}$} & \\
\hline 점수 & & - & & & & & & 범위 2 점수 \\
\hline $\begin{array}{l}\text { 생활공간범위 } 3 \ldots{ }^{*} \\
\text { 걸어서 다닐 수 있는 } \\
\text { 가까운 동네 }\end{array}$ & 예 & 아니오 & $\begin{array}{c}\text { 1번 미만 } \\
/ 1 \text { 주 } \\
1\end{array}$ & $\begin{array}{c}\text { 1-3번 } \\
\text { /1주 } \\
2\end{array}$ & $\begin{array}{c}\text { 4-6번 } \\
\text { /1주 } \\
3\end{array}$ & 매일 & $\begin{array}{l}1=\text { 타인의 도움 } \\
1.5=\text { 보조도구만 사용 } \\
2=\text { 둘 다 필요 없음 }\end{array}$ & \\
\hline \begin{tabular}{|r|} 
점수 \\
\end{tabular} & \multicolumn{5}{|c|}{$x$} & \multicolumn{2}{|c|}{$X$} & 범위 3 점수 \\
\hline $\begin{array}{l}\text { 생활공간범위 } 4 \ldots * \star \\
\text { 동네 밖 인근 읍, 면, } \\
\text { 구 내 장소 }\end{array}$ & 예 & 아니오 & 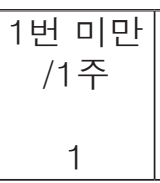 & $\begin{array}{c}\text { 1-3번 } \\
/ 1 \text { 주 } \\
2 \\
\end{array}$ & $\begin{array}{c}\text { 4-6번 } \\
\text { /1주 } \\
3 \\
\end{array}$ & 매일 & \multirow{2}{*}{$\begin{array}{l}1=\text { 타인의 도움 } \\
1.5=\text { 보조도구만 사용 } \\
2=\text { 둘 다 필요 없음 }\end{array}$} & \\
\hline 점수 & & - & & & & & & 범위 4 점수 \\
\hline $\begin{array}{l}\text { 생활공간범위 } 5 \ldots{ }^{* *} \\
\text { 읍, 면, 구 바의 장소 }\end{array}$ & 예 & 아니오 & $\begin{array}{c}\text { 1번 미만 } \\
/ 1 \text { 주 } \\
1 \\
\end{array}$ & $\begin{array}{c}\text { 1-3번 } \\
/ 1 \text { 주 } \\
2\end{array}$ & $\begin{array}{c}\text { 4-6번 } \\
\text { /1주 } \\
3 \\
\end{array}$ & 매일 & $\begin{array}{l}1=\text { 타인의 도움 } \\
1.5=\text { 보조도구만 사용 } \\
2=\text { 둘 다 필요 없음 }\end{array}$ & \\
\hline 점수| & \multicolumn{5}{|c|}{$X$} & \multicolumn{2}{|c|}{$x$} & 범위 5 점수 \\
\hline & & & & & & & 종합점수 & \\
\hline
\end{tabular}

*1 km 이내의 장소

** $10 \mathrm{~km}$ 이내의 장소

*** $10 \mathrm{~km}$ 이상 떨어진 장소 